TAPROBANICA, ISSN 1800-427X. May, 2021. Vol. 10, No. 01: pp. 47-53, pl. 10.

(C) Research Center for Climate Change and Department of Biology, Faculty of Mathematics \& Natural Sciences, University of Indonesia, Depok 16424, INDONESIA.

http://www.taprobanica.org

https://doi.org/10.47605/tapro.v10i1.247

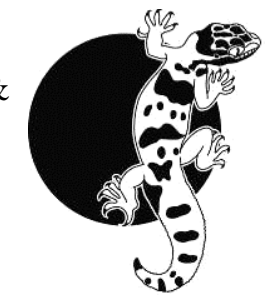

\title{
ABUNDANCE AND FEEDING HABIT OF SQUIRRELS (MAMMALIA: RODENTIA: SCIURIDAE) IN AN URBAN PARK, BANGLADESH
}

\author{
Tanvir Ahmed ${ }^{1}$, Shimul Nath ${ }^{1}$, Habibon Naher ${ }^{1,2}$, Hasanuzzaman Jowel ${ }^{1}$ \& Shamima Nasrin ${ }^{1}$ \\ ${ }^{1}$ Department of Zoology, Jagannath University, Dhaka 1100, Bangladesh \\ ${ }^{2}$ Corresponding author. E-mail: likhi.habibon@gmail.com
}

\begin{abstract}
We studied population abundance and feeding habits of a native squirrel, Callosciurus pygerythrus, and an introduced squirrel, Funambulus pennantii, at Ramna Park in Dhaka City from November 2015 to April 2016. Altogether 459 squirrels were encountered comprising 167 (36.4\%) encounters with $C$. pygerythrus and $292(63.6 \%)$ with $F$. pennantii. The relative abundance of $C$. pygerythrus and $F$. pennantii were 7.0 and 12.3 individuals $/ \mathrm{km}$ of transect respectively. Altogether 92 feeding occasions of squirrels were observed that included 29 occasions of $C$. pygerythrus and 63 occasions of $F$. pennantii. Both species had omnivorous diets while $C$. pygerythrus consumed more fruit $(35 \%$ of all consumed foods) than $F$. pennantii (28\% of all consumed foods). The diets of both species were highly correlated $\left(\chi^{2}=65.1, d f=40, p=0.0073\right)$. Both intra- and inter-specific interactions at food sources revealed competition for limited resources in the park. Population monitoring and further research on various ecological aspects will help to understand their ecological adaptations to the urban setting and their roles in ecosystem health. This will inform management approaches for this important natural area in an urban setting.
\end{abstract}

Key words: Feeding habit, Ramna Park of Dhaka, Sciuridae, squirrel populations, urban biodiversity

\section{Introduction}

In recent years, global biodiversity has been decreasing dramatically due to a wide array of anthropocentric threats (Chase et al. 2020). Urban development fragments the natural landscape, destroys and modifies habitats required for many other species and creates new habitats for some species, at least for those that are not habitat specialists (Lowell et al. 2005). Species of urban landscapes with broad ecological tolerance may show higher biomass and densities, as opposed to the specialists with more narrow tolerance (Lowell et al. 2005). Although a good number of mammals thrive in different urban areas, ecological understanding of many species is limited (Baker \& Harris 2007). Most squirrels are variously adapted for arboreal life, and their dependence on forests has resulted in numerous co-evolutionary relationships with forest plants (Steele \& Koprowski 2001). A few, however, such as the eastern grey squirrel, Sciurus carolinensis, the 
Eurasian red squirrel, Sciurus vulgaris, Pallas's squirrel, Callosciurus erythraeus and the five striped palm squirrel, Funambulus pennantii, colonize well in urban and sub-urban landscapes (Williamson 1983, Hein 1997, Long 2003, Parker 2006, Adriaens et al. 2015). Their natural distribution does not coincide with human habitations, so urbanization changes their occurrence and distribution patterns, population trends and ecology (Bonnington et al. 2014). These urban species should have a different life history strategy than species in forests due to varied disturbances and availability of resources. But this aspect has not yet received sufficient attention (Bonnington et al. 2014). Squirrels, which are almost unstudied in Bangladesh, comprise six species of tree squirrels and three species of flying (gliding) squirrels (IUCN Bangladesh 2015). Two species of squirrels are found in the capital Dhaka city. Irrawaddy Squirrel Callosciurus pygerythrus is native to Dhaka and in the recent past, $F$. pennantii escaped from the National Zoo (Khan 1996) and has spread locally. The original distribution of $F$. pennantii in Bangladesh was restricted to the west of the Brahmaputra River (Khan 1996). No information on the population trends and ecology of these species is available in urban habitats in Bangladesh. The present study was conducted on population abundance and feeding habits of the squirrels at Ramna Park in Dhaka city to have a better understanding of how these species are coping in a human-dominated urban setting.

\section{Material and Methods}

Study area. Ramna Park $\left(23^{\circ} 44^{\prime} 16.5^{\prime \prime} \mathrm{N}\right.$, $\left.90^{\circ} 24^{\prime} 03.1^{\prime \prime E}\right)$ is situated at Shahbag in the Dhaka metropolitan area of Bangladesh covering an area of 68.5 acres (Fig. 1A). It is one of the biodiversity rich areas within the city, a green oasis in the concrete jungle featuring a beautiful and modern venue for relaxation (Rajia et al. 2015). The Park contains 71 species of flowering trees, shrubs, perennials, and annuals. Thirty-six of these are fruit bearing plants, 33 are medicinal plants and 41 are forest trees (Rajia et al. 2015). A total of 50 bird species has been recorded in the park as well as a large colony of the Indian flying fox, Pteropus medius (see Nayem \& Alam 2014, Rajia et al. 2015). A lake inside the park, covering 8.7 acres, originated from a channel of the Karwan Bazar River and once connected to the Turag and Buriganga rivers (Mustafa et al. 2013). The
Department of Environment of Bangladesh looks after the lake's environment and protection of its aquatic resources (Mustafa et al. 2013). There is a restaurant inside the park and visitors enter it for morning and evening walks. There are busy roads on three sides of the park and buildings on the fourth.

Data collection and analysis. We conducted surveys to collect population and feeding habit data on squirrels at Ramna Park from November 2015 to April 2016. A total of 72 hours were spent for data collection over 12 days (2 consecutive days in each month). Of these, 6 days were surveyed in the morning $(06: 00 \mathrm{~h}$ to 12:00 h) and 6 days in the evening (12:00 $\mathrm{h}$ to 18:00 h). We walked a total $23.74 \mathrm{~km}$ along three selected transects (Fig. 1A) conducting 'Complete Counts' methodologies (Sutherland 2000). Observations of feeding habits of the squirrels were noted opportunistically during population surveys. Sex identification of the squirrels was not possible without capturing, and we neither counted nests nor quantified the food amount consumed. We used a Garmin etrex 10 GPS to record location data and the distribution of important fruit plants for squirrels in the park. We also noted animals' interactions while feeding. The consumed food items were classified under three categories: (a) the foods from resident plants, (b) supplementary foods thrown out by visitors and (c) animal matter. We applied Pearson's Chi-squared test to compare the diets of the two squirrel species, and the encounter rate/month between both species using Microsoft Excel 2019. Maps were created using QGIS (ver. 3.4).

\section{Results}

Altogether 459 squirrels were encountered comprising $167 \quad(36.4 \%)$ encounters of Callosciurus pygerythrus and $292(63.6 \%)$ of Funambulus pennantii. On average, there were $38.3 \pm 5.3$ individuals/walk including $13.9 \pm 2.3$ individuals of $C$. pygerythrus and $24.3 \pm 4.7$ individuals of $F$. pennantii. The encounter rate of $C$. pygerythrus and $F$. pennantii were 7.0 and 12.3 individuals $/ \mathrm{km}$, respectively. Encounter locations suggest that $C$. pygerythrus individuals were concentrated at food trees while $F$. pennantii individuals were distributed all over the park (Fig. 1B). Remarkably $86.22 \%$ of all the $C$. pygerythrus sightings were on trees and $64.0 \% \mathrm{~F}$. pennantii were found on the ground. Both squirrels were recorded more often in the morning $(286 ; 62.3 \%)$ than in the evening (173; 


\section{Plate 10}
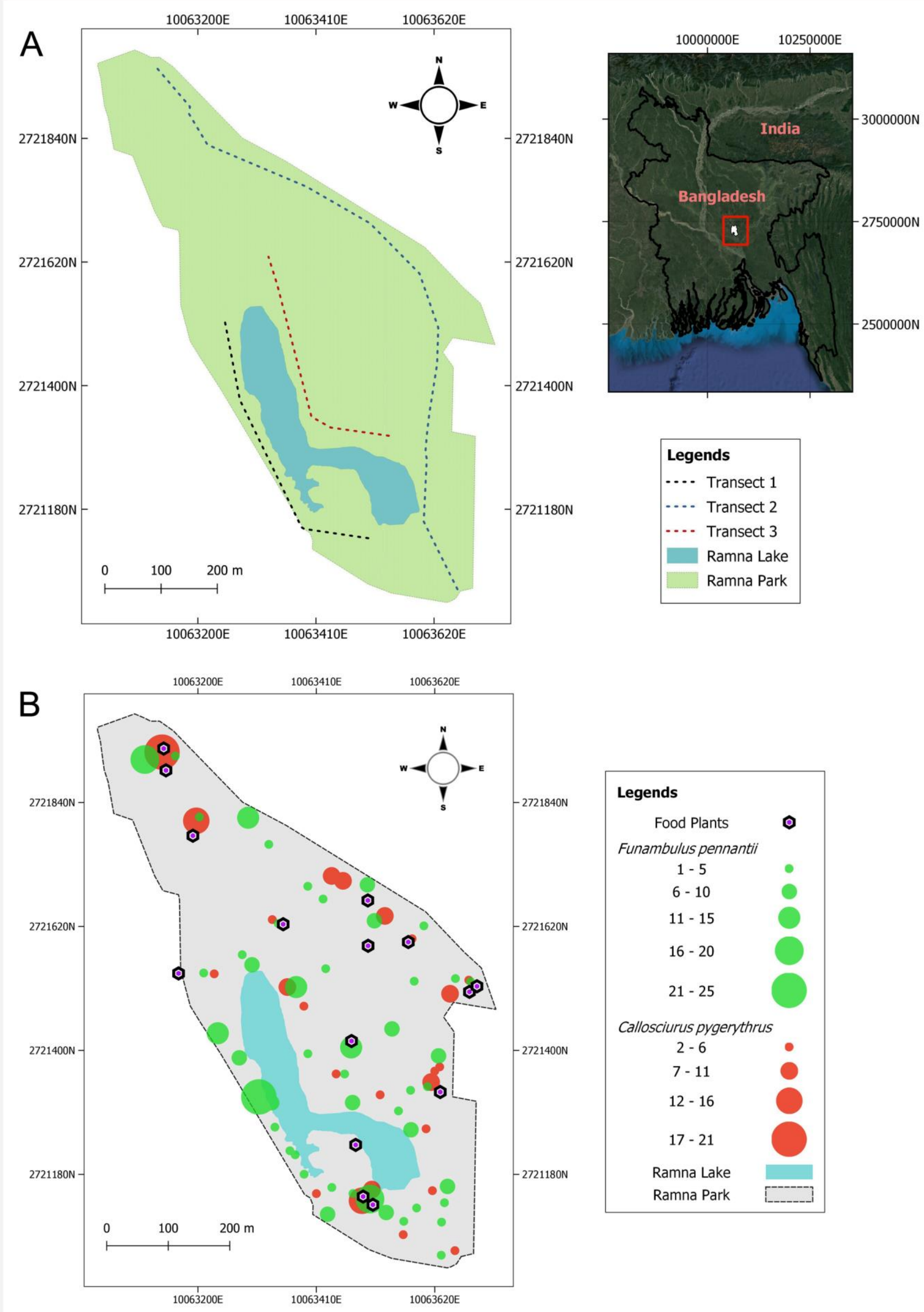

\begin{tabular}{|l}
\hline Legends \\
Food Plants \\
Funambulus pennantii \\
$1-5$ \\
$6-10$ \\
$11-15$ \\
$16-20$ \\
$21-25$ \\
Callosciurus pygerythrus \\
$2-6$ \\
$7-11$ \\
12 - 16 \\
17 - 21 \\
Ramna Lake \\
Ramna Park
\end{tabular}

Figure 1. Map of Ramna Park in Dhaka, Bangladesh showing (A) walkways used as transects and (B) locations and abundances of the two squirrel species and locations of important food plants. 
37.7\%). The highest number of C. pygerythrus was recorded during January and lowest in November while the highest number of $F$. pennantii was recorded during April and the lowest in March (Fig. 2). However, there was no significant difference in the month-wise encounter rate of the squirrels $\left(\chi^{2}=24, d f=20\right.$, $p=0.2424$ ).

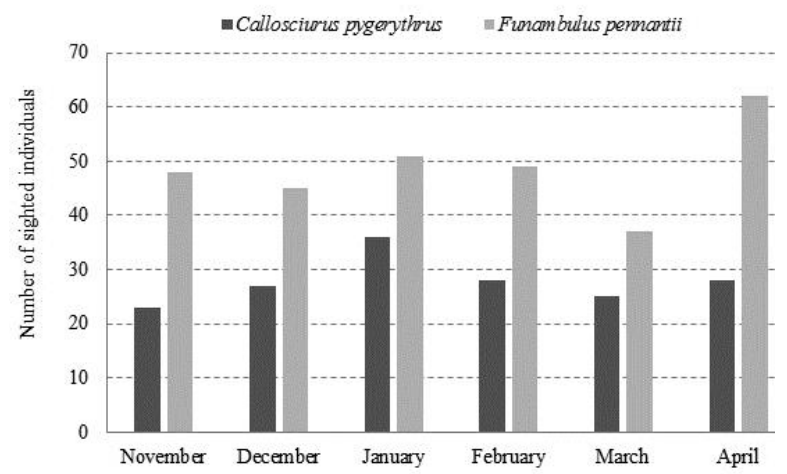

Figure 2: Monthly sighting of two squirrel species at Ramna Park, Dhaka, Bangladesh

Altogether 92 feeding occasions of squirrels were observed that included 29 occasions of Callosciurus pygerythrus and 63 occasions of $F$. pennantii. Both species had omnivorous diets while C. pygerythrus consumed more fruit (35\% of all the consumed foods) than $F$. pennantii ( $28 \%$ of all the consumed foods) (Table 1). The diets of both species were highly correlated $\left(\chi^{2}=65.1, d f=40, p=0.0073\right)$. The squirrels' diets consisted of leaves, fruits, seeds, flowers, and bark of 14 resident plant species (Table 1), and Ficus sp. fruits were the most preferred food item. Different foods were given by visitors including puffed rice, tea and juice, breads, icecream, potato chips and banana. Animal matter included ants, termites, dead odonates (Agriocnemis sp.), bird carcasses of house crow, Corvus splendens, and other unknown insects. Funambulus pennantii tended to feed on visitor's food (70.4\% of all thrown foods) and animal matter (75\% of all animals matter) at a higher rate than $C$. pygerythrus.

We observed competition and commensalism among the squirrels and with other animals (including humans). Almost 60\% of the recorded interactions were competition for foods at different sources. We recorded seven species of birds: coppersmith barbet, Psilopogon haemacephalus; black-headed oriole, Oriolus larvatus; red-vented bulbul, Pycnonotus cafer; chestnut-tailed starling, Sturnia malabarica; Asian pied starling, Gracupica contra; common myna, Acridotheres tristis; and house crow, Corvus splendens) as competitors of both squirrels at the fruit plants. Also, house crows and domestic dogs were competitors for foods thrown out by visitors.

Table 1: Feeding habits of squirrels at Ramna Park, Dhaka, Bangladesh on different plant species; $C p$, Callosciurus pygerythrus; Fp, Funambulus pennantii; — not reported.

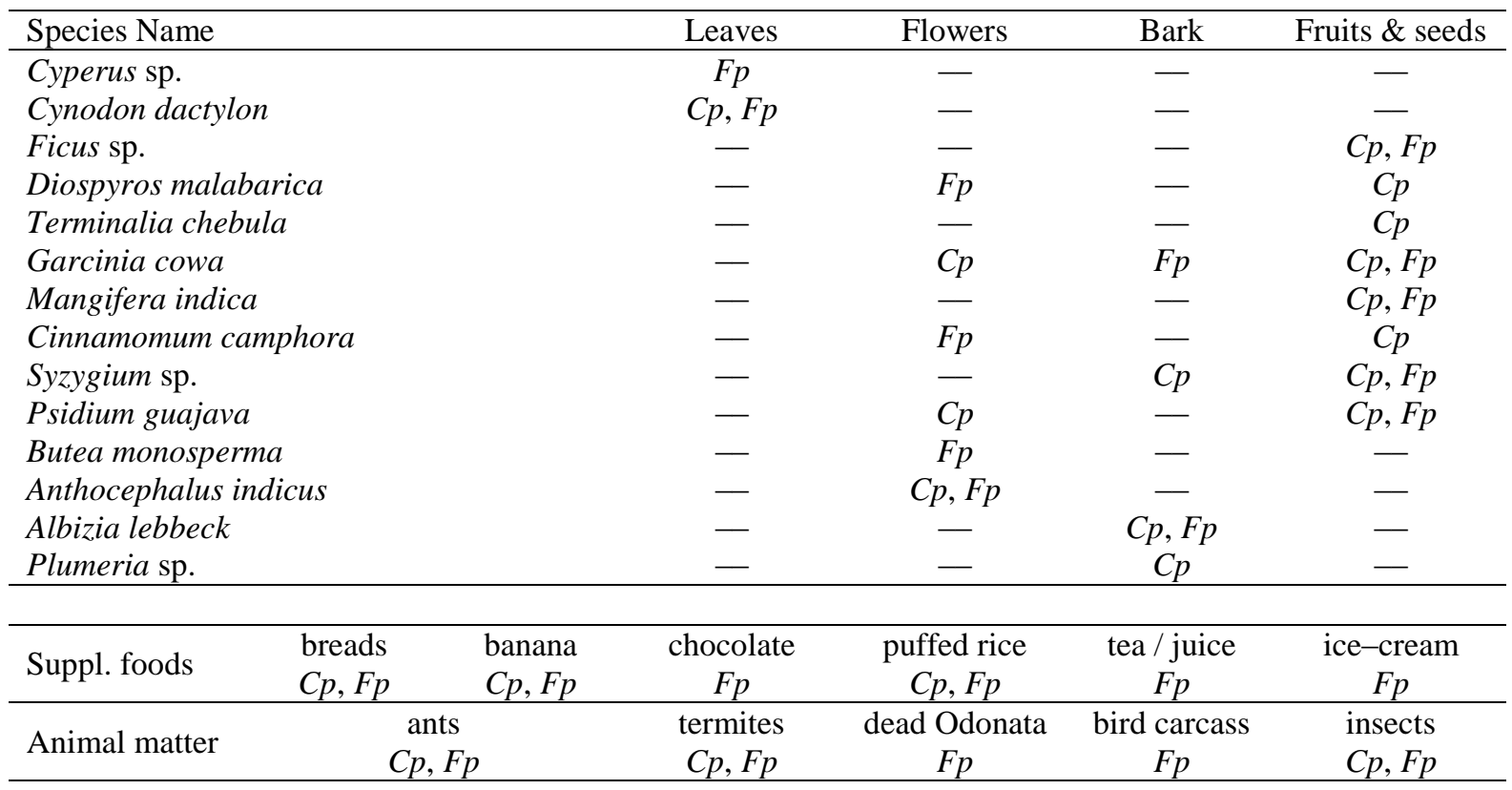




\section{Discussion}

This study reveals $38.3 \pm 5.3$ individuals/walk of squirrels at Ramna Park. The relative abundance of Callosciurus pygerythrus and Funambulus pennantii were 7.0 and 12.3 individuals $/ \mathrm{km}$ of walk respectively. Since there was no prior squirrel population data available at the park, we were unable to examine their population trends. Callosciurus pygerythrus was reported as the most abundant species in logged forests and plantations with the relative abundance ranging from 0.11 to 1.58 individuals per $\mathrm{km}$ walk (Datta \& Goyal 2008, Datta \& Nandini 2014, Duckworth 2016). The density of $C$. pygerythrus was also reported to be higher in plantations (10.1 individuals per $\mathrm{km}^{2}$ ) and in heavily logged forests $\left(23.4\right.$ per $\left.\mathrm{km}^{2}\right)$ than in lightly logged forests $\left(1.8\right.$ per $\left.\mathrm{km}^{2}\right)$ and in unlogged primary forests (2.7 per km²) (Datta \& Goyal 2008, Datta \& Nandini 2014, Duckworth 2016). Callosciurus pygerythrus was more frequently observed in secondary forests than in primary forests, and most often around settlements, cane shrubs at the edge of the forest, plantations, and agricultural areas (Smith \& Xie 2008, Thorington et al. 2012, Thapa et al. 2016). So, it was inferred that $C$. pygerythrus is adaptable to high degrees of habitat modification as a generalist species (Duckworth 2016).

Similarly, $F$. pennantii is also known to be a highly adaptable species in diverse habitat types including tropical and subtropical dry deciduous forests, montane forests, grasslands, scrublands, plantations, arable lands, rural gardens, agricultural lands, urban areas and introduced vegetation (Molur et al. 2005, IUCN Bangladesh 2015, Nameer \& Molur 2016). During the $19^{\text {th }}$ Century $F$. pennantii was introduced to Zoos of Australia and established feral populations in the urban areas that also revealed higher densities (10-130 squirrels per $\mathrm{km}^{2}$ ) (Seebeck 2013). Wright (1972) observed that $F$. pennantii density increased with the availability of supplementary foods, fruiting, and nesting trees. Datta \& Goyal (2008) added the degree of arboreality factor beside food and nesting requirement to have an impact on the abundance of squirrels. One plausible reason for higher abundance of $F$. pennantii than $C$. pygerythrus at Ramna Park was feeding on supplementary foods.

Both $F$. pennantii and $C$. pygerythrus had omnivorous diets consisting of plant material (leaves, flowers, bark, fruit, and seeds), animal (vertebrate carcass and invertebrates) and different food thrown out be visitors in Ramna
Park (Table 1, Fig. 3). With our small data set of scattered individuals, it is uncertain whether there are significant differences among their feeding habits although our data shows similarities to their known feeding habits. For example, C. pygerythrus was reported to feed on flower buds, fruits, bark, seeds, leaves, latex, insects, nectar, lichen, vertebrates and date juice (Ghosh 1981, Datta \& Goyal 1997, Smith \& Xie 2008, Thorington et al. 2012, IUCN Bangladesh 2015).

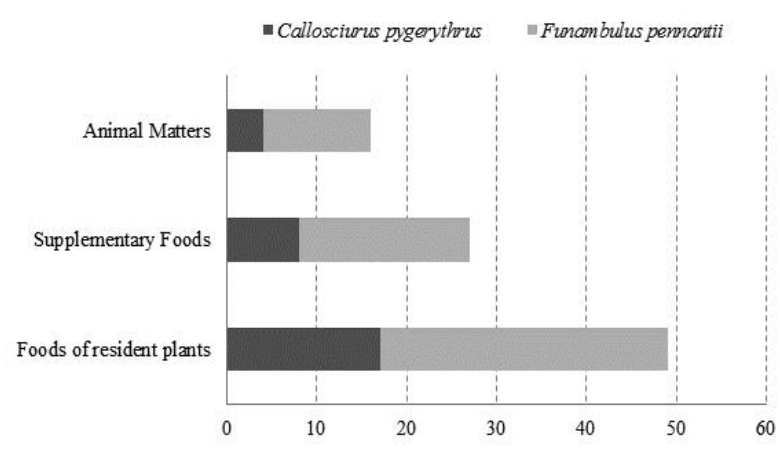

Figure 3: Feeding habit of two squirrel species at Ramna Park, Dhaka, Bangladesh

Similarly, F. pennantii is known to feed on tender shoots, fruit, vegetables, leaves, boiled rice and bread offered by people, honey from unprotected beehives, some small animals (such as birds, lizards), bird's eggs and insects (dipteran larvae, coleopteran larvae, termites and caterpillars) (Mitchell 1979, Prater 2005, Meena et al. 2012, Thorington et al. 2012, Shihan 2013, IUCN Bangladesh 2015, Thapa et al. 2016). Interestingly, grass leaves (Cyperus sp., Cynodon dactylon) was the most preferred food item in village habitats for $F$. pennantii (Shihan 2013) whereas higher consumption of fruit and seeds (Ficus sp.) was recorded for both squirrels at our urban site. Flowers and fruit of Dyabanga grandiflora, Bombax ceiba and Chukrasia tabularis and bark of Pterospermum acerifolium, Kydia calycina were identified as important resources for $F$. pennantii in disturbed forests (Datta \& Nandini 2014, Duckworth 2016). In contrast, Palm squirrel, Funambulus species prefer insects as protein source more than fruit and nuts, when the fruit and vegetal resources are in same proportions (Barnett \& Prakash 1975, Tiwari 1990, Balasubramanian 1995, Méndez-Carvajal et al. 2016). Palm Squirrels also eat seeds throughout the year, leaves and soft fruits during autumn, and insects, particularly locusts, during summer and do not 
cache food (Seebeck 2013). The seasonality and availability of supplementary foods might therefore have an impact on their feeding habits that can be varied in urban landscapes where the resources are limited.

Although Ramna Park is a small reservoir of a good number of fruit plants and additional food resources to support a number of animals (Rajia et al. 2015, Nahar et al. 2017), both interand intraspecific interactions at the squirrels' food sources revealed competition for food in this park. Competition for food resources can be a primary mechanism for displacement of native species by the introduced species and often results in significant negative impacts on native fauna (Long 2003, Johnston et al. 2019). Interspecific competition negatively affects the fecundity, growth, or survival of one, or both species, and its effects are considered to be density dependent (Wauters et al. 2002). So, monitoring the squirrel populations at Ramna Park along with detailed studies on their feeding habits and ecological niche partitioning will be valuable to help understand if the native $C$. pygerythrus population is affected by the introduced $F$. pennantii in the urban setting.

Both $C$. pygerythrus and $F$. pennantii are listed as "Least Concern" in Bangladesh and globally by IUCN Red List of Threatened Species (IUCN Bangladesh 2015, Duckworth 2016, Nameer \& Molur 2016). The only possible mammalian predator at Ramna Park that eats rodents is the Small Indian Mongoose Herpestes auropunctatus (Cavallini \& Serafini 1995). Among the birds at the park, the Black Kite Milvus migrans was reported to hunt $F$. pennantii (Kumar et al. 2014). Although these squirrels are hunted for meat and display elsewhere (Molur et al. 2005, Nameer \& Molur 2016), there is no such exotic hunting risk at Dhaka City. Further studies focusing on the management strategies of these squirrel population at Ramna Park should be prioritized, because the squirrel populations are not only important for the aesthetic value to the visitors but also play important ecological roles in this urban ecosystem, for example, as seed dispersal. In this highly urbanized landscape, such small urban parks could also play a role as potential suitable refuges to promote biodiversity conservation by providing habitat and resources for urban fauna (Cornelis \& Hermy, 2004). Population monitoring and further research on various ecological aspects will help to understand their ecological adaptations to the urban settings and their roles in ecosystem health. This will inform management approaches for this important natural area in an urban setting.

\section{Acknowledgements}

The authors acknowledge IDEA WILD, USA for providing research equipment, Hasan Rahman for supplying a few important literatures, Feroze Ahmed for sharing his personal laptop and Jennifer Lewis for important suggestions. Authors are grateful to Vijay Kumar Koli for his valuable comments to improve the manuscript.

\section{Literature cited}

Adriaens, T., K. Baert, P. Breyne, J. Casaer, S. Devisscher et al. (2015). Successful eradication of a suburban Pallas's squirrel Callosciurus erythraeus (Pallas 1779) (Rodentia, Sciuridae) population in Flanders (northern Belgium). Biological Invasions, 17 (9): 2517-2526.

Baker, P.J. and S. Harris (2007). Urban mammals: what does the future hold? An analysis of the factors affecting patterns of use of residential gardens in Great Britain. Mammal Review, 37(4): 297-315.

Balasubramanian, P. (1995). Some notes on the fruits, seeds and nectar consumed by Threestriped palm squirrel Funambulus palmarum at Point Calimere Wildlife Sanctuary, Tamil Nadu. Journal of the Bombay Natural History Society, 92 (1): 256-258.

Barnett, S.A. and I. Prakash (1975). Rodents of Economic Importance in India. Arnold Heinemann, New Delhi: 175pp.

Bonnington, C., K.J. Gaston, and K.L. Evans. (2014). Squirrels in suburbia: influence of urbanization on the occurrence and distribution of a common exotic mammal. Urban Ecosystem, 17 (2): 533-546.

Chase, J.M., S.A. Blowes, T.M. Knight, K. Gerstner, and F. May (2020). Ecosystem decay exacerbates biodiversity loss with habitat loss. Nature, 584: 238-243.

Cornelis, J. and M. Hermy (2004). Biodiversity relationships in urban and suburban parks in Flanders. Landscape \& Urban Plan, 69 (4): 385-401.

Cavallini, P. and P. Serafini (1995). Winter Diet of the Small Indian Mongoose, Herpestes auropunctatus, on an Adriatic Island. Journal of Mammalogy, 76 (2): 569-574.

Datta, A. and R. Nandini (2014). Sciurids. In: Johnsingh, A.J.T. and N. Manjrekar (eds.). 
Mammals of South Asia. Volume 2. University Press, Hyderabad: 534-535.

Datta, A. and S.P. Goyal (1996). Comparison of forest structure and use by the Indian giant squirrel (Ratufa indica) in two riverine forests of Central India. Biotropica, 28 (3): 394-399.

Datta, A. and S.P. Goyal (2008). Responses of diurnal tree squirrels to selective logging in western Arunachal Pradesh. Current Science, 95 (7): 895-902.

Duckworth, J.W. (2016). Callosciurus pygerythrus. The IUCN Red List of Threatened Species 2016: e.T3604A22253451. Downloaded on 18 May 2020.

Ghosh, S. (1981). Observation on the carnivorous habitat of an Irrawaddy squirrel, Callosciurus pygerythrus (Geoffrey). Journal of the Bombay Natural History Society, 77 (1): 316317.

Hein, E.W. (1997). Environmental auditingdemonstration of line transect methodologies to estimate urban Gray Squirrel density. Environmental Management, 21 (6): 943-947.

IUCN Bangladesh (2015). Red List of Bangladesh, Volume 2, Mammals. IUCN Bangladesh Country Office, Dhaka: 232pp.

Johnston, A.N., D. Stephen, W. West, and M.V. Haegen (2019). Diets of native and introduced tree squirrels in Washington. Journal of Wildlife Management, 83 (7): 1598-1606.

Koprowski, J.L. and R. Nandini (2008). Global hotspots and knowledge gaps for tree and flying squirrels. Current Science, 95 (7): 851-856.

Khan, M.A.R. (1996). Bangladesher Bonnyaprani Volumes 1-3. Bangla Academy. Dhaka: 148 pp.

Kumar, N., D. Mohan, Y.V. Jhala, Q. Qureshi, and F. Sergio (2014). Density, laying date, breeding success and diet of Black Kites Milvus migrans govinda in the city of Delhi (India). Bird Study, 61 (1): 1-8.

Long, J.L. (2003). Introduced mammals of the world: their history, distribution \& influence. CSIRO Publishing, Australia: 612pp.

Lowell, W.A., L.W. VanDruff, and M. Luniak (2005). Managing urban habitats and wildlife. In: Braun, C.E. (ed.). Techniques for wildlife investigations and management, $6^{\text {th }}$ edition, The Wildlife Society, Bethesda: 974pp.

Méndez-Carvajal, P.G., K.D. Prasad, M.S.K. Pagadala et al. (2016). Brief Observations of Natural Behaviour for Indian five striped squirrel Funambulus pennantii, Telangana, India. Small Mammal Mail, 8 (1): 14-19.

Meena, S.S., V.K. Koli, C. Bhatnagar, and S.K. Sharma (2012). Predation on northern house gecko Hemidactylus flaviviridis Rüppell by female northern palm squirrel Funambulus pennantii Wroughton. Journal of the Bombay Natural History Society, 109 (3): 198-199.

Mitchell, R.M. (1979). The Sciurid rodents (Rodentia: Sciuridae) of Nepal. Journal of Asian Ecology, 1 (1): 21-28.

Molur, S., C. Srinivasulu, B. Srinivasulu, S. Walker, P.O. Nameer, and L. Ravikumar (2005). Status of non-volant small mammals: Conservation Assessment and Management Plan workshop report. Zoo Outreach Organisation/CBSG-South Asia, Comibatore: $618 p p$.

Mustafa, T., S.M.I. Alam, M.S. Jamal, F.T. Johora et al. (2013). Abundance of benthic fauna in winter and summer seasons at three water bodies of Dhaka, Bangladesh. Bangladesh Journal of Zoology, 41 (1): 79-86.

Nameer, P.O. and S. Molur (2016). Funambulus pennantii (errata version published in 2017). The IUCN Red List of Threatened Species 2016: e.T8702A115088099. Downloaded on 18 May 2020.

Nayem, Z. and S.M.I. Alam (2014). Status of the roosting population of Indian Flying Fox Pteropus giganteus in Ramna Park, Dhaka. The Festschrift on the 50th Anniversary of The IUCN Red List of threatened Species, IUCN Bangladesh, Dhaka: 192pp.

Nahar, S., M.T. Akter, S.S. Khan. S. Jahan et al. (2017). Winter assemblage of birds and mammals on the fruited canopy of Ficus bengalensis and Ficus religiosa at Ramna Park, Dhaka, Bangladesh. Jagannath University Journal of Life \& Earth Science, 3 (1-2): 14-21.

Prater, S.H. (2005). The Book of Indian Animals. $3^{\text {rd }}$ edition. Bombay Natural History Society, Mumbai: 194-201pp.

Parker, T.S. (2006). Habitat and landscape characteristics that influence population density and behavior of Gray Squirrels in urban areas. PhD Thesis. University of Missouri: 101pp.

Rajia, S., M.M. Alam, G.W. Chowdhury, M. Akash, and M. A. Islam (2015). Status and diversity of birds of Ramna Park, Dhaka, Bangladesh. Bangladesh Journal of Zoology, 43 (2): 291-301.

Sutherland, W.J. (2000). Ecological Census Technique: A Handbook. Cambridge University Press, UK: 446pp.

Seebeck, J.H. (2013). Sciuridae. Fauna of Australia <www.environment.gov.au> Accessed on 23 September 2020. 
Seto, K.C., B. Guneralp, and L.R. Hutyra (2012). Global forecasts of urban expansion to 2030 and direct impacts on biodiversity and carbon pools. Proceedings of the National Academy of Sciences, 109 (40): 16083-16088.

Smith, A. and Y. Xie (2008). The Mammals of China. Princeton University Press, Princeton, New Jersey: 576pp.

Shihan, T.R. (2013). Food habits of Northern Palm Squirrel Funambulus pennantii Wroughton, 1905 in Chuadanga District, Bangladesh. S. Mammal Mail, 5 (1): 14-15.

Steele, M.A. and J.L. Koprowski (2001). North American tree squirrels. Smithsonian Institution, Washington D.C., USA.

Thorington, K.K., J.L. Koprowski, M.A. Steele, and J.F. Whatton (2012). Squirrels of the world. Johns Hopkins University Press, Baltimore: 459pp.

Thapa, S., H.B. Katuwal, S. Koirala B.V. Dahal, B. Devkota et al. (2016). Sciuridae (Order: Rodentia) in Nepal. Small Mammals Conservation and Research Foundation, Kathmandu: 62pp.

Tiwari, J. (1990). Five striped squirrel Funambulus pennantii (Wroughton) killing birds. Journal of the Bombay Natural History Society, 87 (1): 137.

Wauters, L.A., J. Gurnell, A. Martinoli, and G. Tosi (2002). Interspecific competition between native Eurasian red squirrels and alien grey squirrels: does resource partitioning occur? Behavioral Ecology \& Sociobiology, 52 (4): 332-341.

Wright, J.M. (1972). The biology of Funambulus pennanti Wroughton, feral in Western Australia. BSc Thesis, University of Western Australia, Perth: 78pp.

Williamson, R.D. (1983). Identification of urban habitat components which affect eastern Gray Squirrel abundance. Urban Ecology, 7 (4), 345-356. 